although the operation is described as very difficult, and one which few surgeons would have the skill to perform."

So far from this being correct, rules and directions abound, not only in the extracts above-quoted, but in other parts of my pamphlet; in fact, as far as words can convey a knowledge of the application of the wool, I have given it. The latter part of the statement is equally incorrect.

3. "That the terms artificial membrana tympani or artificial tympanum are never used.'

It is true that the term artificial tympanum was not used in the first edition of my pamphlet; but it was the term naturally given to my remedy immediately upon its introduction both by patients and practitioners. I have before me a letter from Dr. Noggerath, of Brussels, dated Sept. 11th, 1849, in which he speaks of having read an account of my interesting discovery of the "artificial tympanum." "Incongruous" it may be; but no other term will properly designate the object of the remedy. If Mr. Toynbee can supply me with another equally expressive, $I$ will gladly adopt it ; for I have no desire that my invention should be confounded with an artificial membrana tympani of gutta percha or any other substance.

And now we come to a quotation from the work of Mr. Tod, published in 1833, which testifies to the "relief derived from the mere introduction of a little lint into the external meatus in those cases where the membrana tympani has been ruptured or destroyed by disease." How greatly astonished will the reader of this quotation be that Mr. Tod never availed himself of this fact amongst his patients! Instead of detracting from the merit of my discovery, of applying artificial substances to the meatus for the purpose of improving the hearing, because the fact is thus briefly adverted to in published works of ancient date, I confidently contend that my merit is the greater for having been the first practically to apply the treatment, and reduce it to a system. It had been noticed by Itard in 1820 , and by Deleau in 1821, as $I$ have elsewhere shown, and yet no advan. tage had been taken of the fact in medical practice by either of those practitioners. Books of great merit have been published on Diseases of the Ear since 1833, including those of Mr. Pilcher and Dr. Kramer, but no mention is made of any such treatment up to the period of the publication of my papers in Trre Larreet, in 1848 .

I have no hesitation in expressing my conviction that isolated cases have occurred from the beginning of the world of persons with diseased tympana finding out some means of temporarily relieving themselves of deafness by the application of some in genious contrivance.

The reader has probably heard of the renown which attaches to a strip of bacon-fat as a remedy for deafness. Who can doubt but that it arose from that substance having been used by some fortunate patient with a perforated tympanum?

Whether the enunciation of my mode of treatment, in 1848 led to Mr. Toynbee's "researches" in 1850, I know not. Mr. Toynbee does not admit the fact, though it would have been no discredit to him had he done so. It is this want of candour, and a suppressio veri, of which $r$ have so much to complain. $\mathrm{He}$ invents an artificial membrana tympani. To gain popularity for it he propounds a theory, the truth of which is highly problematical. He sends in a paper to the Royal Society, without one word of the existence of the cotton remedy; another to the Society of Arts, equally devoid of candour, and thus surreptitiously obtains a medal for a modification of an invention which honestly belongs to another.

Mr. Toynbee winds up his paper to which this is a reply, by saying,

"Considering that in my pamphlet I have given full credit to those who recommended (although quite empirically) the use of the cotton wool, \&c."

Why not say, him (Mr. Yearsley) instead of those, for who but myself recommended it?

The conclusions upon which I take my stand are,-

Ist. - The artificial membrana tympani, as proposed by $\mathrm{Mr}$. Toynbee, is a modification only of material for the production of the same effect which is more easily attained by the intro. duction of wetted cotton.

2nd. - Cases of perforated tympana alone are remedied by either or any appliance.

3rd.- Whatever the substance employed, the perforation must not be completely covered; a communication must be maintained with the outer air.

4th. - The good effect is generally immediately noticeable when a click or pop is heard, and this is produced by the bursting of a bubble of air, or the admission of air through the discharge which is present in cases of diseased tympana on the site of the perforation. 5th. - The good effect is maintained only so long as the substance employed, whatever be its nature, occupies a position which will render that support to the ossicula of which they have been deprived by the partial or entire loss of the membrana tympani.

6th. - Cotton-wool is preferable to all other substances and appliances, because-

1. It is more easily applied.

2. It is more simple, safe, and cleanly.

3. It retains its proper position longer.

4. It causes no irritation.

5. It produces no noises in the ear whilst eating or talking.

6. It confers more comfort to the patient than any other known substance.

7. It produces the highest degree of hearing of which a patient with perforated tympanum is susceptible.

I now leave it to the reader to judge whether or not $\mathrm{Mr}$. Toynbee has appropriated unfairly, and without due acknowledgment, the idea which I promulgated through the columns of THE LANCET and other sources in 1848 .

Savile-row, November, 1855 .

ON A

\section{CASE OF SPONTANEOUS LUXATION OF THE TIBIA OUTWARDS,}

THE CONSEQUENCE OF DISEASE OF THE ARTICULATINGSTRUCTURES OF THE KNEE-JOINT.

By HENRY CRITCHLEY BRODRICK, M.D., ASSISTANT-SURGEON 3RD PALAMCOTTAH LIGHT INFANTRT, H.E.I.C.S. MADRAS.

ON the 4 th of September, 1855, my attention was drawn to a case just brought into the Charity Hospital attached to this place, (Paulghautcherry, Malabar, ) the details of which, with a sketch, I subjoin.

Sheikh Madarh, aged fifty-eight, a wandering fakir, formerly residing in Arcot, admitted with dislocation of the tibia of the left leg outwards, and synovial inflammation of the right kneejoint, with threatened luxation of the corresponding tibia.

This man has been a nomad all his life, earning his subsistence by singing and playing a rude kind of fiddle. He has been throughout his lifetime constantly exposed to every vicissitude of climate, sleeping in the jungle and forest, when unable to obtain any other shelter. Up to the last eight years he had enjoyed excellent health, in spite of the debauched life which, in common with all his class (fakirs), he confessed to having led. At this date he perceived a swelling on the left knee, accompanied with a great deal of pain in the joint, which followed an unusually long carouse, and consequent exposure to the violence of the prevailing monsoon; at the same time he felt "sinew-bound" in the ankle, heel, and neighbourhood of the tuberosity of the ischinm.

For this affection he consulted a native surgeon, who bled him with a rude kind of cupping instrument, in the neighbourhood of the knee. He obtained no relief from this treatment, but matters went from bad to worse until about two months after the cupping, when the joint suddenly became luxated whilst walking. The accident was attended with agonizing pain, which became gradually mitigated until about four months after the accident, when it somewhat suddenly ceased. No attempt to remedy the displacement had been made.

Thus matters went on until two months prior to the present date, when, whilst walking, he began to feel a pain in the right knee, which was relieved when he sat down, coming on again whenever he moved. He now commenced a series of experiments in toddy and arrack drinking, the results of which he described to me most naively. He considered-he saidthat toddy was bad for the pain, but that arrack was a great comfort. Coincident with the pain, swelling gradually took place in the joint, and both symptoms have gradually increased; he now, too, began to feel the contraction of the tendons that he remembered suffering from whilst the left knee was affected.

Present State.-In the Left Knee, the tibia is incompletely dislocated outwards from the condyles of the femur, which are driven inwards and downwards, the onter condyle of the femur resting on the inner edge of the head of the tibia ; the patella, which seems small, is perched almost on the summit of the mass; the muscles of the thigh are atrophied. The limb is most easily maintained in a semi-flexed position, in which the tendon of the biceps is tense and exceedingly prominent. On moving the joint, the various inequalities of the articular surfaces are felt. The outer condyle of the femur is easily tilted 
to a slight extent further on to the bead of the tibia. The popliteal artery is felt most easily, the adipose tissue of the ham having been in a great measure absorbed. The patient can flex and extend the limb with ease, the parts having accommodated themselves to their new position wonderfully ; but when he suddenly extends the limb, after perfect flexion, a deal of aching pain is felt, and the hand placed over the mass detects a general creaking of synovia which is audible throughout the ward.

In the Rig7t Knee there is a vast, soft, elastic swelling, over all the anterior face of the articulation, extending backwards to the hamstrings, and upwards until lost about one-fourth up the thigh. The tumour bulges most internally, and conveys to the touch the feeling of a thin sac of india-rubber distended with air. Externally, the head of the fibula and of the tibia are easily felt, and the inner condyle of the thigh-bone is bending over to the internal side. The joint is most easily maintained in a semi-flexed position; the hamstrings of either side are tant and very rigid, especially the tendon of the biceps. Walking is attended with great pain in the joint, but in spite of this he manages to stump about with the aid of a long bamboo. It is very evident that this articulation is destined speedily to suffer a like fate with its fellow; indeed, the man will hail this with great satisfaction, as a relief from the pain he suffers at present.

If this case could be watched until the man's death, dissection would no doubt reveal many strange changes in the mechanism of the joint; but such is the wandering life of the fakirs, that it is extremely improbable that I shall ever see him again.

I have wormed out of this poor wretch as much of his history as I could. In a few days more he will be away on his travels, and some day, when worn out by age or disease, he will lie down to die in the jungle, and the tiger and vulture will share what remains of this "wandering minstrel."

Paulghaut, Malabar.

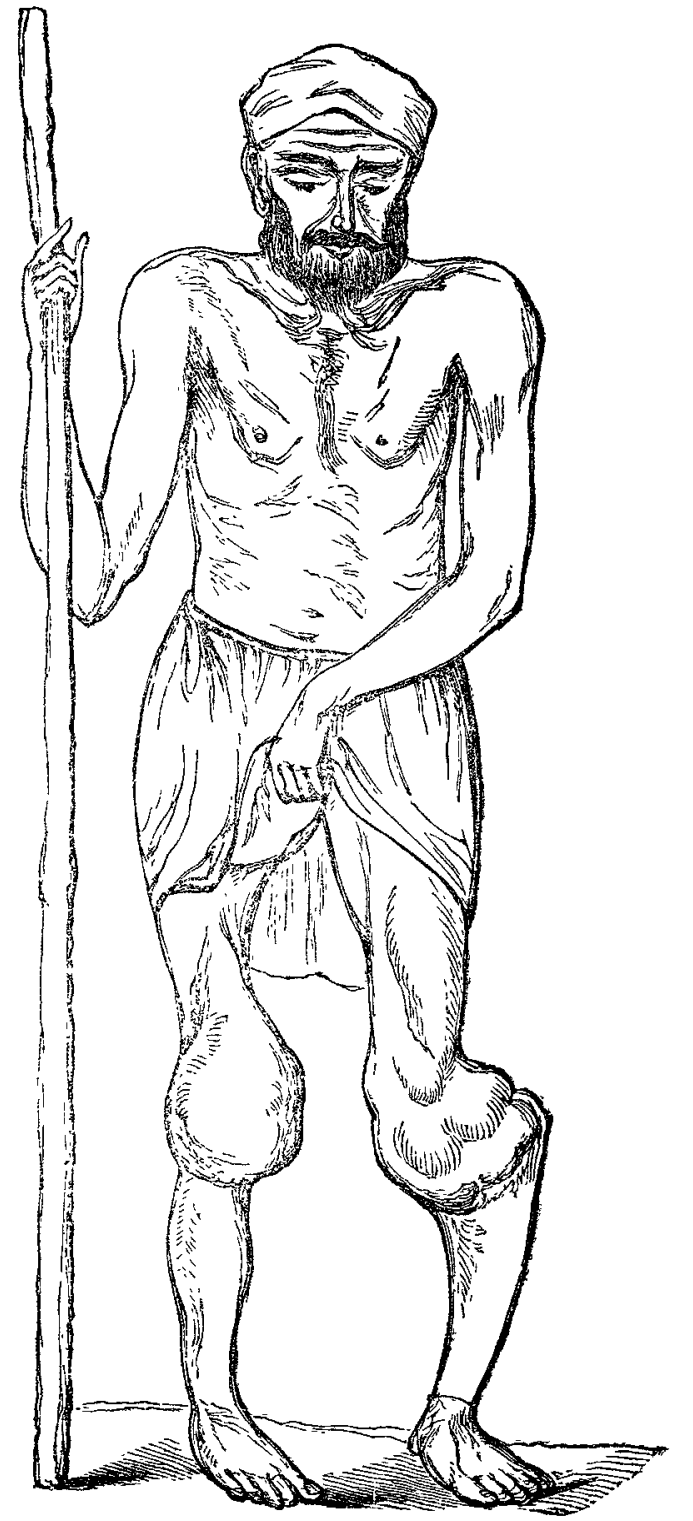

468

\section{g 炡lintor}

OF THE PRACTICE OF

MEDICINE AND SURGERY

HOSPITALS OF LONDON.

Nulla est alia pro certo noscendi via, nisi quam plurimas et morborum et dissectionum historias, tam aliorum proprias, collectas habere et inter se comparare.-Morgagni. De Sed. et Caus. Morb. lib. 14. Procemium.

\section{ST. BARTHOLOMEW'S HOSPITAL.}

PHAGEDANA, AND ITS RELATION TO SYPHILIS; TREATMENT, \&C. (Under the care of Mr. LAWREYCE.)

IT is sometimes instructive to observe the value of old experience in the treatment of obstinate maladies, more particularly when modern theory, which is not always the case, can afford an explanation of what time has already settled. We were very much interested lately, in going through Mr. Lawrence's cases, with some clinical observations of the oldest of our hospital surgeons on subjects no longer so difficult to be understood as in his earlier practice, when Abernethy and Hunter ruled the schools. It does not require the teaching of Oesterlen or Mill to satisfy Mr. Lawrence that each case of disease is a study in itself, and that two sick patients, though apparently labouring under the same affection, may require exactly opposite treatment, notwithstanding all that statistics or observations drawn from other countries may do to rank them together under one head.

The cases which formed subjects of Mr. Lawrence's observa. tions were two of phagedæna-in fact, of phagedæna in its very worst form, and requiring the most active remedies. One, he said, seemed to him to be phagedæna because it was syphilis; the other syphilis because it was phagedæna. For one form of phàgedæna he believed mercury was specific as a cure; for the other, specific as a poison. One seemed to be, as he said, phagedænic $a b$ initio; it was that of a stout, healthy-looking man, fresh from the country, whose glans and prepuce, if not the whole penis, was threatened with destruction from that form of syphilis which seems to have the greatest affinity with phagedænic action. The second case was that of an unfortunate young woman, "exercising her dismal vocation," as expressed by Mr. Lawrence, for nearly a month with a large ulcer, that was first perhaps a very simple sore, but now from neglect threatening to destroy all the parts, if not her life. One sore began as syphilis, and would go through its stages as such, while the other began as a primary sore of a simple kind.

CASE 1.-H. S-_, aged forty-six, was admitted into St. Bartholomew's, under Mr. Lawrence, Oct. 16th. Though apparently in perfect health, having lived almost all his life in the country, he had come up to town to put himself under the care of Mr. Lawrence for a large sloughing phagedænic mass of ulceration, involving the entire glans and prepuce. It has now existed for five weeks, and seems rather spreading than diminishing. The edges of the ulcer appear somewhat excavated, and there is a suspicious Hunterian indurated margin. Some surgeons would employ chlorate of potash or opium; Mr. Lawrence thought, on the other hand, that the patient's only chance was in mercury. Two grains of calomel and a quarter of a grain of opium were accordingly ordered every three hours, till the mouth became sore. Mr. Lawrence explained to his class that this would be very bad practice in some cases of phagedæna, but here it did not seem as if the syphilitic half of the mischief had been yet reached.

19th. - Mouth not yet affected. Ordered meat diet and porter, and to go on with the mexcury.

21st. - The sore is better; the mercury has certainly stopped the phagedæna. He is now to have opium lotion and nitrio acid. The case subsequently did well. Mr. Lawrence had only been fearful that the parts would be all destroyed before the mouth became influenced by the remedy.

CASE 2.-Jane $\mathrm{H}-$ - aged sixteen, a well-nourished girl, who states that she has been diseased for a fortnight, applied in another department of the hospital, Uct. 18th. There appear immense swelling and a phagedænic sore of the left 